\title{
PERJUANGAN MELAWAN STIGMATISASI SUANGGI \\ DALAM MASYARAKAT
}

Oleh: Drs. Remigius Ceme, Lic.

\begin{abstract}
Abstraksi:
A rtikel ini mencoba memahami fenomena suanggi dalam perspektif teologi Katolik. Satu pengajaran iman yang mengedepankan cinta kasih sebagai medium untuk merangkul orang-orang yang dituduh

suanggi dan sering dikucilkan dari lingkup pergaulan sosial. Kepercayaan terhadap suanggi yang kental menjauhkan manusia dari cinta kasih kristiani yang berjuang mengangkat martabat orang-orang yang terpinggirkan karena berhadapan dengan kemalangan dan penyakit. Pribadi-pribadi tertentu sering dituduh sebagai suanggi yang menyebabkan orang lain sakit, menderita kemalangan atau bahkan meninggal. Dengan demikian artikel ini menawarkan satu perspektif yang lain untuk melawan stigmatisasi yang keliru terhadap pribadi-pribadi tertentu yang dituduh suanggi. Ajaran-ajaran teologi Katolik dipakai sebagai dasar pijak dalam menggumuli fenomena suanggi dalam masyarakat.
\end{abstract}

Kata kunci: suanggi, stigmatisasi suanggi, teologi, cinta kasih.

\section{Pengantar}

Tema ini menampakkan bahwa kepercayaan kepada suanggi sudah begitu mengakar dalam budaya dari hampir setiap kelompok masyarakat. Kenyataan dalam masyarakat kita menunjukkan bahwa setiap kemalangan atau penyakit atau sakit selalu dikaitkan dengan suanggi. Bagi banyak masyarakat, suanggi adalah:

Manusia atau semacam manusia yang memiliki kekuatan gaib dan bersifat jahat. Mereka membenci manusia dan melalui kekuatan gaib yang mereka miliki, mereka membuat orang jatuh sakit. Seringkali dianggap, bahwa mereka makan daging manusia, daging orang-orang yang dibunuhnya. Suanggi bisa juga mengirim roh jahat ke dalam orang lain, sehingga orang itu kerasukan dan disiksa oleh roh itu (Kirchberger, 2007:335).

Melihat definisi ini dengan teliti, mungkin orang berpikir bahwa suanggi sama dengan manusia yang hidup bersama manusia lain, yang mengintip orang-orang tertentu untuk disakiti dan dibunuh dengan kekuatan gaib yang dimilikinya. Orang atau keluarga yang satu menstigmatisasi orang atau keluarga lain sebagai suanggi yang harus selalu diawasi dan dipisahkan dari pergaulan dan semua relasi. Stigmatisasi seperti ini membawa kesulitan tersendiri bagi karya pewartaan iman Katolik, yang hanya percaya kepada Allah melalui Yesus Kristus. Bagaimana seseorang dapat mewartakan cinta Allah dalam Yesus Kristus yang adalah inti iman Katolik kepada orang-orang yang berkeyakinan seperti ini? Masalah suanggi merupakan masalah yang penting dalam relasi antara orang yang satu dengan yang lain. Relasi yang seharusnya didasarkan pada cinta tidak dapat dijalankan dengan baik, karena stigmatisasi. Di banyak tempat bahkan terjadi perlakuan-perlakuan yang diskriminatif dan tidak manusiawi. Tulisan ini, akan membahas bagaimana teologi berupaya menjawab fenomena stigmatisasi ini.

\section{Stigmatisasi Suanggi}




\subsection{Suanggi}

Dalam bahasa Inggris kita temukan 2 (dua) nama untuk suanggi, yaitu sorcery dan witchcraft (Zocca and Urame, 2008: 13-14). Sorcery didefinisikan sebagai kekuatan jahat yang diperoleh dengan belajar dari orang lain atau dengan berpuasa dan bermatiraga. Sedangkan witchcraft dideskripsikan sebagai kekuatan jahat yang dapat bekerja secara otomatis dan tidak dikehendaki. Biasanya sorcery dikenakan pada laki-laki dan witchcraft ditujukan pada perempuan. Karena itu pemahaman tentang suanggi dalam definisi ini lebih diarahkan untuk yang berjenis kelamin perempuan daripada yang berjenis kelamin laki-laki. Dalam pemaparan tertulis pada umumnya di Eropa, yang memiliki kekuatan magik adalah perempuan, sehingga banyak sekali perempuan yang diadili dan dibunuh karena dituduh sebagai suanggi yang membawa malapetaka dan kesialan untuk orangorang lain (Zocca and Urame, 2008: 23).

Apa yang dilakukan suanggi tidak diketahui orang lain dan selalu bersifat rahasia, yang hanya diketahui oleh suanggi itu. Semua yang tabu tidak diakui. Mereka dapat melakukan perkawinan incest dan bersetubuh dengan roh-roh dan binatang. Mereka dapat berubah rupa dan pergi ke tempat lain untuk melakukan kejahatan sementara badan fisik tetap tinggal di rumah. Tempat tinggal para suanggi yang berubah-ubah itu adalah pekuburan dan tempat-tempat yang dianggap keramat. Dalam kehidupan sehari-hari pergaulan mereka sangat terbatas dan tingkah laku mereka kelihatan aneh dan asosial. Mereka dikatakan arogan dan bangga dengan kekuatan magik yang dimiliki untuk membunuh dan memakan tubuh orang lain.

Suanggi dalam masyarakat NTT atau Indonesia umumnya juga diidentifikasi dengan ciri-ciri tertentu. Dikatakan suanggi tidak mandi, pakaian tak teratur, pergaulan sangat terbatas, menyukai dunia malam atau kegelapan, wajahnya pucat dan keadaan fisiknya tidak menarik. Mereka dapat berubah rupa menjadi binatang malam. Kalau binatang malam berbicara, maka diyakini bahwa suanggi sedang beraksi. Mereka suka berkeliaran pada malam hari, khususnya bila ada kematian. Katanya mereka akan memakan mayat orang yang sudah meninggal (kanibal) secara bersama-sama. Mereka tidak datang untuk memangsa orang yang telah meninggal dalam bentuk tubuh fisiknya sebagai manusia, tetapi dalam bentuk dan rupa anjing, burung gagak atau binatang lain. Kehadiran suanggi diasosiasikan dengan suara-suara binatang malam yang menakutkan, bunyi-bunyi yang dirasa tidak biasa dan dari pantatnya keluar api.

Dalam masyarakat atau budaya NTT atau Indonesia umumnya, suanggi itu dikenakan pada semua orang yang diyakini memiliki kekuatan magik jahat, baik laki-laki maupun perempuan, bahkan seluruh keluarga. Kalau orangtua dari satu keluarga suanggi, maka semua keturunannya akan menjadi suanggi. Ini yang dinamakan suanggi keturunan. Keyakinan seperti ini menjelaskan bahwa suanggi diturunkan secara biologis. Tetapi ada juga kepercayaan bahwa orang menjadi suanggi karena proses belajar atau tinggal dalam waktu yang lama di tempat-tempat haram, seperti di hutan atau di atas gunung.

Suanggi sering diartikan sebagai roh jahat dalam rupa manusia yang memiliki kekuatan magik untuk mendatangkan penyakit dan kemalangan. Pengertian ini mengandung pemahaman bahwa suanggi hanyalah suatu khayalan untuk menjawab sumber segala kemalangan dan penderitaan yang manusia alami. Jawaban itu memuaskan kerinduan hati terdalam terhadap pertanyaan-pertanyaan eksistensial yang mengganggu ketenteraman hidup manusia. Stigmatisasi suanggi berawal dari upaya mencari jawaban atas kenyataan pahit hidup manusia yang tidak bisa diterima.

Dari apa yang disampaikan di atas, ada pertanyaan yang muncul: apakah suanggi itu real atau dapat ditemukan di dalam masyarakat sebagai orang yang selalu berniat mendatangkan penderitaan, penyakit, kemalangan dan kesialan bagi orang-orang lain? Atau apakah suanggi menjadi sumber dari semua chaos dalam kehidupan manusia? Orang-orang yang masih hidup dalam situasi "tradisional", yang masih mendapat ceritacerita dari pendahulunya pasti yakin bahwa suanggi itu betul-betul ada dalam bentuk dan rupa yang 
menakutkan, yang membawa malapetaka bagi kehidupan orang-orang lain. Tetapi dalam dunia post-modern orang tidak dapat membayangkan begitu saja sosok badani suanggi. Para antropolog dan sosiologpun tidak berkeyakinan demikian. Tulisan mereka hanya mengedepankan cerita-cerita yang sudah menjadi budaya masyarakat "tradisional" tanpa membenarkan atau menyalahkan. Secara ilmiah, eksisitensi suanggi tidak diterima dengan akal sehat, sehingga kepercayaan itu disebut sebagai superstisi (Zocca and Urame, 2008: 1920).

\subsection{Stigmatisasi}

Kata stigma (Arndt and Gingrich, 1979: 768), berasal dari bahasa Yunani yang memiliki konotasi positif, terutama dalam konteks religius. Tetapi dalam pemakaian sehari-hari arti ini berubah menjadi negatif seperti yang sekarang ditemukan dalam beberapa kamus (Pusat Bahasa Departemen Pendidikan Nasional, 2005: 1091 dan Crowther, 1995: 1171). Stigmatisasi suanggi adalah penilaian yang diberi nama tertentu, seperti polo, u'en, manake, poti wolo, kepada seseorang atau keluarga atau kelompok orang yang diyakini (hanya dalam cerita) sebagai yang memiliki kekuatan jahat, yang merusakkan kehidupan orang lain. Pandangan seperti ini terus hidup dalam masyarakat secara turun-temurun, sehingga timbul diskriminasi dan perlakuan yang tidak manusiawi pada mereka yang dianggap suanggi.

Sebetulnya adanya stigmatisasi dapat disebabkan oleh ketidakpahaman atau kurangnya pengetahuan orang untuk memecahkan masalah-masalah penting dalam kehidupannya, seperti penderitaan atau penyakit atau kematian. Penyakit dan rasa sakit yang diderita seseorang pertama-tama tidak ditafsir sebagai akibat terinfeksi virus atau terjangkit penyakit malaria misalnya, tetapi dipandang sebagai perbuatan dari seorang suanggi. Demikianpun kematian. Kematian tidak dianggap sebagai batas akhir hidup manusia yang dari segi iman dilihat sebagai bentuk pertanggungjawaban seseorang kepada Allah karena dosa, tetapi oleh perbuatan mistis-magis suanggi. Suanggi adalah penyebab penderitaan, sakit, malapetaka, dan kematian.

Stigmatisasi terhadap suanggi semakin diperkuat oleh orang yang disebut dukun. Dukun dideskripsikan sebagai orang yang mempunyai kekuatan melampaui orang-orang lain, yang dapat mengetahui penyebab dari semua penderitaan, kesakitan, malapetaka, dan kematian. Biasanya bila seorang sakit atau sering gagal dalam usahanya, ia pergi ke dukun dan bertanya mengapa hal-hal itu terjadi pada dirinya. Dukun selalu memberitahukan bahwa yang ada di balik penderitaan dan kesialan itu adalah suanggi. Atau bila ada kematian, seorang dukun dipanggil dan ditanyai sebab kematian orang bersangkutan. Diyakini, dukun mengetahui semua rahasia yang tidak diketahui oleh orang lain. Suanggi menjadi tertuduh utama penyebab kematian. Apa yang dikerjakan dukun hanyalah bayangan ilusif terhadap suanggi. Dia sendiri tidak pernah melihat dan mengetahui seperti apa dan seperti siapa suanggi itu. Ketika ditanya tentang identitas suanggi, dia tidak dapat menjawabnya dengan pasti. Hanya dijawab bahwa dia mengenal suanggi dari mimpi dan penglihatan yang terang. Penglihatan yang terang itu tidak dijelaskan. Karena itu dukun sebetulnya adalah pemalsu kebenaran, penyebar ketidakharmonisan masyarakat dan penyebab utama perlakuan yang tidak manusiawi terhadap orang yang dituduh suanggi. Tetapi banyak sekali orang yang masih tetap percaya pada sepak terjang dukun dalam masyarakat.

Stigmatisasi suanggi dapat berasal dari pandangan masyarakat karena diceritakan secara turun-temurun dan diperkuat dengan praktik-praktik dukun yang menyebut bahwa setiap kemalangan, penderitaan, penyakit dan kematian disebabkan oleh orang lain yang dijuluki suanggi. Stigmatisasi seperti ini tidak membawa dampak yang baik bagi kehidupan bermasyarakat dan dengan sendirinya juga kehidupan Gereja sebagai umat Allah.

\section{Teologi Menjawab}




\subsection{Kembali ke Kitab Suci}

Kepercayaan pada suanggi sudah ada sejak manusia eksis di atas bumi ini dan membentuk masyarakat. Ada relasi antara anggota masyarakat. Relasi selalu dikaitkan dengan keharmonisan dan ketenteraman setiap anggota. Tuduhan-tuduhan terhadap sesama anggota dalam masyarakat sudah ada sejak manusia diciptakan Allah. Adam menuduh Hawa sebagai penyebab dosa dan Hawa menuduh ular sebagai penghasutnya sehingga ia berbuat dosa (Kej 3: 12-13). Ketidakpercayaan dan kecurigaan ini terus melekat dalam diri manusia selanjutnya hingga hari ini. Hal tersebut menimbulkan ketidaknyaman, penderitaan, dan bahkan kematian. Posibilitas berdosa tetap dibawa oleh setiap orang yang lahir dan tinggal di dunia ini, yang disebut concupiscentia.

Dalam masyarakat dewasa ini, termasuk masyarakat yang beragama, kepercayaan akan roh-roh jahat tetap ada dan mengambil bentuk semacam "agama asli” yang mereka anut. Kepercayaan akan suanggi berawal dari kepercayaan akan roh-roh jahat yang memengaruhi kehidupan manusia. Keyakinan yang kuat akan adanya suanggi, yang melahirkan dualisme kepercayaan dalam diri Gereja, umat Allah, mengantar orang beriman untuk mencari solusi yang signifikan dan bermanfaat bagi kehidupan beriman dalam Gereja Katolik.

Kitab Suci Perjanjian Lama dengan tegas melarang segala bentuk praktik kepercayaan pada kekuatankekuatan, yang menghalangi keperayaan kepada Allah. Kitab Ulangan 18: 10-14 menegaskan bahwa seseorang yang percaya kepada Allah harus melepaskan semua praktik berhala. Perintah pertama dalam dekalog mengajarkan semua orang yang beriman kepada Allah untuk membebaskan diri dari semua bentuk penyembahan berhala, yaitu praktik menghormati allah-allah lain dalam wujud makluk atau benda-benda ciptaan Allah sebagai pengganti Allah.

Perintah pertama ini mengecam keberhalaan. Diminta dari manusia supaya hanya beriman kepada Allah, dan bukan kepada allah-allah lain, dan supaya tidak menghormati allah-allah lain di samping Allah yang Esa. Kitab Suci mendesak terus-menerus untuk menolak berhala-berhala......Pemujaan berhala tidak hanya ditemukan dalam upacara palsu di dunia kafir, ia juga merupakan satu godaan yang terus-menerus bagi umat beriman. Pemujaan berhala itu ada, apabila manusia menghormati dan menyembah sesuatu hal yang tercipta sebagai pengganti Allah, apakah itu dewa-dewa atau setan-setan (umpamanya satanisme) atau kekuasaan, kenikmatan, bangsa, nenek-moyang, uang atau hal-hal semacam itu.....Pemujaan berhala tidak menghargai Allah sebagai Tuhan yang satu-satunya; dengan demikian ia mengeluarkan orang dari persekutuan dengan Allah (Embuiru, 1995: 544).

Banyak sekali kutipan Perjanjian Lama yang melarang semua kepercayaan sia-sia dan penyembahan berhala, karena semua itu dilakukan terhadap apa yang diciptakan Allah. Padahal Allah jauh lebih besar kekuasaan-Nya di atas semua yang Dia ciptakan. Contoh penolakan Perjanjian Baru terhadap semua yang bersifat magik dan sihir muncul dalam Surat St. Paulus kepada Umat di Galatia 5: 19-20: "Kamu tahu apa yang termasuk perbuatan-perbuatan daging: percabulan, kemesuman, kecerobohan, penyembahan berhala, sihir, kebencian,iri hati dan kekerasan, pertemtangan dan ingat diri.....”. Perjanjian Baru melihat bahwa magi dan sihir adalah kepercayaan sia-sia yang melawan Allah. Magi dan sihir dalam masyarakat diyakini dimiliki oleh suanggi, sehingga apa saja yang dilakukannya bersifat jahat dan mendatangkan penderitaan, penyakit, rasa sakit, kematian dan malapetaka lainnya. Semua ini dikaitkan dengan pengaruh setan, yang menghendaki supaya manusia berbalik dari Allah (Zocca and Urame, 2008: 21). 
Kitab Suci tidak mengindikasikan bahwa semua kemalangan, penderitaan, penyakit dan kematian berasal dari praktik-praktik jahat dari orang-orang yang hidup dalam masyarakat (Zocca and Urame, 2008: 21) yang disebut suanggi. Yang diperlihatkan Kitab Suci ialah bahwa, selain kekuatan Allah, semua kekuatan yang lain, dilarang untuk dihormati dan disembah oleh manusia. Suanggi yang diyakini memiliki pengaruh kuat dan menguasai hidup dan mati setiap orang tidaklah benar, karena hanya Allah yang menentukan hidup dan mati seseorang.

Dalam praktik hidup sehari-hari, masyarakat percaya pada kekuatan-kekuatan mistik-magik. Kepercayaan ini juga membawa orang untuk percaya pada kekuatan jahat, yang katanya hidup dalam masyarakat dan menyebabkan penderitaan, rasa sakit dan kematian, yaitu suanggi. Dalam masyarakat Flores atau NTT umumnya, kepercayaan pada suanggi ini sudah ada sebelum agama Katolik masuk. Karena itu upaya pewartaan cinta sebagai intisari Injil Kristus kepada orang-orang yang percaya akan suanggi merupakan tugas yang berat dan harus dijalankan secara bertanggungjawab dalam iman kepada Yesus Kristus.

\subsection{Cinta: Dasar dan Tujuan Perjuangan Melawan Stigmatisasi Suanggi}

Suanggi adalah kekuatan mistik-magik, penyebab misterius penderitaan, penyakit, dan kematian bagi manusia. Kekuatannya luar biasa dan hanya dapat dihalangi atau didamaikan oleh orang yang disebut dukun. Tetapi hal yang sangat tragik dalam kepercayaan ini ialah bahwa domain kekuatan jahat suanggi itu dituduhkan pada orang-orang tertentu, sehingga terjadi perlakuan yang tidak adil, diskriminatif dan tidak manusiawi terhadap orang yang dituduh suanggi itu. Dan semua jenis perlakuan tersebut, melawan hukum pertama dan terutama, cinta kasih. Suanggi bukan lagi didefinisikan sebagai kekuatan jahat tetapi sebagai oknum-oknum atau individu-individu dengan kepribadian tertentu, yang sehari-hari hidup bersama orang-orang lain. Mereka dicap dengan label seseorang yang selalu mempunyai niat dan kehendak untuk mengganggu ketenteraman orang-orang lain, bahkan menjadi pembunuh berdarah dingin. Anggapan seperti ini tidak pernah dapat dibuktikan dalam realitas. Belum ada orang yang melihat dengan mata kepala sendiri suanggi sebagai seseorang yang hidup bersamanya.

Banyak yang berkhayal dan memikirkan dalam imajinasinya saja bahwa orang ini suanggi dan orang itu tidak. Ada banyak sekali cerita tentang apa yang dilakukan oleh suanggi. Tetapi ini semua cuma hasil imajinasi atau khayalan, karena tak pernah ada orang yang melihatnya dalam wujud nyata. Belum ada orang yang pernah membunuh binatang, yang menurut anggapan orang adalah penjelmaan suanggi, yang berarti membunuh suanggi dalam rupaseseorang yang ada di sekitarnya. Belum ada orang yang dapat membuktikan rupa macam apa suanggi itu. Yang biasa disebut dalam masyarakat adalah khayalan belaka, yang diturunkan dari mulut ke mulut dan dianggap sebagai kebenaran. Mungkin ini adalah pengaruh dari kecenderungan berbuat dosa yang senantiasa bercokol dalam diri setiap orang (Ceme, 2015: 19).

Mekanisme dosa, yaitu bahwa orang kehilangan kepercayaan akan Allah sebagai sumber dan penjamin hidup, menghasilkan suatu ketakutan eksistensial akan kehilangan hidup dengan dayanya sendiri atas ongkos orang lain. Hakikat kejahatan dan kesalahan manusia ini menjadi sangat terang dalam kepercayaan akan roh-roh jahat (suanggi), di mana mereka dianggap menjamin dan mempertahankan hidup mereka sendiri dengan membunuh orang lain (Kirchberger, 2007:336).

Meskipun identitas suanggi tak dapat dilihat dan hanya diceritakan, perlakuan terhadap orang yang dituduh suanggi tak dapat dipertanggungjawabkan. Mereka dianggap bukan manusia lagi. Kalau seorang 
manusia dianggap bukan manusia, padahal dalam kenyataan dia adalah manusia, bagaimana praktik hukum terbesar Kristus, cinta kasih, dalam kehidupan nyata orang Kristen? Yesus berkata:“....kasihilah sesamamu manusia seperti dirimu sendiri" (Mat 12: 39). Hukum kasih inilah yang sesungguhnya menjadikan semua orang harus diterima dan dihormati sebagai saudara dan saudari. Padahal orang yang dituduh sebagai suanggi menjadi orang yang terpinggirkan, tersingkir, dan dilecehkan secara tidak berprikemanusiaan, bahkan dapat dibunuh begitu saja, karena mereka tidak dianggap sebagai manusia lagi.

Dalam pengalaman sehari-hari bisa terlihat bahwa ada orang yang kerasukan setan atau roh jahat. Coba bandingkan dengan tindakan Yesus ketika mengusir setan dari orang Gerasa (Lk 8: 26-39). Yesus bertanya kepadanya: "Siapakah namamu?" Jawabnya: "Legion”. Memang sering sekali si setan di dalam orang yang kerasukan itu akan menyebut nama orang yang kita kenal kalau ditanya. Kita mesti lebih teliti untuk mengatakan bahwa nama yang disebut ini adalah orang yang menyebabkan orang lain menderita. Bahaya bagi setiap orang yang dipercaya mempunyai kharisma yang Tuhan berikan adalah mengklaim bahwa orang yang namanya disebut si sakit adalah suanggi. Yesus tidak menyebut sama sekali bahwa ada orang yang merasuki orang ini, tetapi setan yang menyebabkan penderitaan seperti itu. Setan mempunyai sifat dan kekhasan merusakan hubungan antara manusia, menimbulkan dendam kesumat dalam diri orang, permusuhan dan perselisihan bahkan pembunuhan orang yang dianggap suanggi. Atau dalam Injil juga, ketika Yesus menyembuhkan seorang anak yang sakit (Lk 9: 37-46a). Roh jahat menyerang anak itu dengan berteriak-teriak dan menggoncang-goncangkannya sampai mulutnya berbusa dan menyiksanya, lalu keluar darinya. Setan selalu membuat kepribadian seseorang tidak dapat tenang dan bahagia. Dia mau supaya manusia menderita dan saling menuduh. Dalam kaitan dengan suanggi, setan menggunakan keyakinan ini untuk menjerat manusia supaya manusia saling menuduh, membenci, berselisih, bermusuhan, bahkan saling membunuh. Ini yang menjadi kesulitan bagi semua yang membantu orang yang sakit dengan kharisma yang Tuhan berikan kepadanya untuk berdoa dan membebaskan sesama dari pengaruh roh jahat.

Praktik perdukunan sering menjadi biang yang menghidupkan tuduhan terhadap orang yang dianggap suanggi, yang telah melakukan hal yang buruk kepada pasien. Dukun mengatakan pasien sakit sebagai akibat dari perbuatan orang yang dianggap suanggi, padahal dukun sendiri tidak tahu persis model macam apakah suanggi itu. Cerita demi cerita sekitar suanggi tersebar luas karena dituduh sebagai pelaku kejahatan pada orang-orang lain, terutama yang sakit dan yang mengalami kerugian atau kegagalan dalam usaha. Praktik seperti ini menjadi sasaran misi keselamatan Gereja. Sebagai orang beriman, orang Katolik mestinya sudah melepaskan kepercayaan semacam ini. Kalau tidak, maka orang tersebut percaya kepada dua tuhan. Kepercayaan kepada dua tuhan ini menjadikan orang Katolik tidak dapat menghayati imannya secara penuh kepada Kristus, sang Kasih itu sendiri. Karena dalam diri orang seperti itu, kepercayaan kepada Kristus selalu digandeng dengan kepercayaan kepada suanggi. Ada keyakinan ganda (dualisme) dalam masyarakat Katolik yang menyebabkan iman kepada Allah tidak matang dan tidak dapat dihayati secara baik. Kiranya Dualisme keyakinan seperti ini kiranya menjadi salah satu fokus perhatian pastoral dari para pewarta Sabda Allah.

Lewat berbagai peristiwa tragis seputar isu suanggi di antara orang Katolik, menunjukkan bahwa setan masih tetap mengusai peri hidup masyarakat Katolik dewasa ini. Karena dengan sebutan suanggi sudah terjadi pemecahbelahan dan pelanggaran hak hidup orang laindalam diri yang tertuduh. Pemecahanbelahan satu orang dari yang lain adalah perbuatan setan dan akan terus diusahakan terjadi dalam keluarga dan mayarakat beriman. Pelanggaran atas hak hidup orang yang dituduh suanggi juga merupakan tindakan nyata karya roh jahat di tengah-tengah orang beriman. Sebagai orang Katolik yang percaya kepada Tuhan Yesus Kristus, setiap orang mesti menyadari bahaya kekuatan setan yang bekerja siang malam dalam hati dan dalam masyarakat Katolik. 
Hidup dalam cinta yang diajarkan dan dipraktikan oleh Yesus hanya menjadi slogan kosong kalau orang tetap percaya kepada suanggi. Iman Katolik mengajarkan bahwa tidak ada kekuatan lain yang melampaui kekuasaan Allah, Tuhan Yesus Kristus. Kalau demikian, maka keyakinan yang memecahbelahkan dan yang menjadikan orang lain "musuh" adalah keadaan nurani yang anti Kristus. Yesus berkata: "Kasihilah Tuhan Allahmu dengan segenap hatimu, dan dengan segenap jiwamu dan dengan segenap akal budimu.....dan kasihilah sesamamu manusia seperti dirimu sendiri" (Mat 12: 37. 39). Ini berarti, apabila seseorang menuduh orang lain sebagai "musuh" dan patut "dihabisi", orang itu mengkhianati imannya dan dirinya sendiri. Menuduh orang sebagai suanggi adalah tindakan yang keji yang melawan kemanusiaan, karena melawan hukum yang terutama dan pertama iman kristiani: cinta. Yang melawan hukum cinta berarti melawan kehidupannya sendiri dan menolak hidup bahagia.

Setan dapat masuk ke dalam tubuh manusia, terutama mereka yang lemah imannya dan selalu percaya pada kekuatan-kekuatan mistis-magis. Situasi yang seperti ini membuka peluang terbaik bagi setan untuk masuk ke dalam badan manusia. Usaha setan selalu mengacaukan manusia dan membuat situasi manusiawinya amburadul. Situasi tidak aman dan kacau-balau adalah kesukaan si iblis. Buka dan baca Injil di mana Yesus mengusir setan dan selamilah perkataan dan tindakan Yesus yang mengasihi tanpa batas. Tentang ini Gaudium et Spes menegaskan:

Manusia hidup dalam dunia berarti manusia hidup dalam peperangan terus-menerus melawan pengaruh setan, karena dunia dipahami sebagai panggung sejarah manusia yang ditandai oleh kegiatan-kegiatannya oleh kegagalan dan keberhasilannya yang diimani sebagai ciptaan Allah yang jatuh dalam perbudakan setan namun dibebaskan oleh Kristus (GS 16) (Pranjana, 2005: 161).

Iman kepada Allah dalam Yesus Kristus menjadi patokan dan pedoman utama dalam memerangi setiap perihidup berhala yang berkembang dalam masyarakat. Menjadi Katolik berarti melepaskan semua yang bertentangan dengan cinta yang diwartakan dan diteldani oleh Yesus Kristus seperti yang dibaca dalam Injil. Suanggi sebagai satu fenomen berhala dan superstisi harus dapat dieliminasi dari kehidupan setiap umat beriman Katolik. Dengan demikian, Allah dalam Yesus Kristus tetap menjadi sumber dan arah seluruh kehidupan manusia. Penderitaan, sakit, dan kematian diterima dalam terang iman sebagai keadaan natural manusia karena dosa dan manusia berjuang mengatasi problem eksistensial ini dalam iman kepada Allah, kendati masih saja ada keyakinan akan adanya suanggi yang memorak-porandakan kehidupan manusia. Suanggi bukan sandaran kehidupan manusia, tetapi hanya Allah sajalah yang menjadi sandaran kehidupan manusia beriman.

Keyakinan akan adanya suanggi yang menyebabkan penderitaan dan kematian seseorang menghasilkan mentalitas kambing hitam. Barangkali mentalitas "kambing hitam" dipakai sebagai bentuk jawaban atas misteri kematian yang tak terpahami. Pada pokoknya sebagai homo sapiens manusia mempunyai kecenderungan dasar untuk mengetahui sebab dari suatu kejadian yang menggugat eksistensinya. Demikianpun dengan kematian. Kematian begitu misterius dan enigmatik. Kemisteriusan kematian ini mengganggu pikiran manusia dari saat ke saat. Dalam hal kematian orang yang dicintai seperti istri atau suami atau orangtua atau anak atau sahabat, orang merasa sangat terpukul dan terbebani oleh perasaan tak berdaya dan tak mengerti. Orang tidak akan dapat bertahan kalau perasaan seperti ini bercokol terus dalam dirinya. Dia harus mencari pelepasan. Salah satu pelepasan -sekalipun tidak seluruhnya- ialah dengan mencari kambing hitam penyebab kematian tersebut, yang dipersonifikasi dalam diri orang yang dianggap sebagai "suanggi". Dengan ini semua beban, perasaan tak berdaya dan tak mengerti, keputusasaan dan pemberontakan dalam diri orang tersebut dilampiaskan pada pihak 
yang dituduhkan (suanggi), yang dianggap penyebab kematian orang yang dicintai. Dengan berbuat begini orang mendapat jawaban tertentu, yang bisa dijadikan senjata (secara tidak sadar) melawan apa yang ada dalam dirinya sendiri. Jadi, strategi "kambing hitam" sebetulnya merupakan usaha dari orang yang merasa tak berdaya untuk melawan ketakberdayaannya sendiri dengan memproyeksikannya kepada orang lain. Objek dirinya sendiri diganti dengan objek lain di luar dirinya. Dalam psikologi dikenal dengan "defense mechanism”, yang diwujudkan dalam bentuk proyeksi atau agresi atau pemindahan objek(Ceme, 2015: 93).

Dan mungkin sekali, bahwa suanggi sering berfungsi sebagai kambing hitam bagi suatu kelompok sosial tertentu, bahwa kelompok itu memproyeksikan secara tidak sadar rasa salah mereka kepada orang tertentu dan dengan demikian membersihkan diri dengan mengkambinghitamkan orang atau keluarga tertentu sebagai suanggi (Kirchberger, 2007:336).

Sangat boleh jadi menuduh orang lain sebagai suanggi adalah bentuk nyata pelampiasan hati dan pikiran yang tidak memahami apa yang sedang terjadi atau apa yang sedang diderita oleh anggota keluarga. Jawaban atas misteri kematian diungkapkan dalam bentuk tuduhan pada sesama sebagai suanggi, penyebab utama kematian seseorang dan yang menuduh menjadi puas untuk sementara waktu. Mentalitas menjadikan sesama sebagai yang jahat merupakan mentalitas bukan pengikut Yesus Kristus. Berhadapan dengan kepercayaan seperti ini, ajaran Katolik menjadi koreksi untuk segala yang bertentangan dengan kasih yang merupakan prinsip utama hidup manusia, yang merupakan inti ajaran Yesus Kristus. Hidup yang berlandaskan kasih adalah hidup seorang Katolik, pengikut Yesus Kristus. Yang berlawanan dengan cinta berarti berlawanan dengan Yesus Kristus, Tuhan dan Penyelamat.

Seorang beriman Katolik harus melandaskan seluruh kehidupannya pada cinta Yesus Kristus, agar dapat terhindar dari segala macam superstisi dan kepercayaan berhala yang dilawan oleh Gereja. Iman dan cinta kasih harus menjadi dasar, pijakan dan arah dasar kehidupan orang beriman. Dengan menghayati dan mengamalkan iman dan cinta, orang beriman akan dibebaskan dari fenomena kepercayaan kepada kekuatankekuatan mistis magis, seperti kepercayaan kepada suanggi dalam masyarakat, yang sampai saat ini masih kuat diyakini keberadaannya. Pembebasan dari kepercayaan kepada suanggi memberikan peluang bagi setiap anggota Gereja untuk menjadikan sesama sebagai saudara dan saudari dalam wadah Gereja, Umat Allah, yang mengharapkan keselamatan dalam Yesus Krsitus.

\section{Penutup}

Kepercayaan kepada suanggi telah menjadi semacam "agama kedua" dalam masyarakat terutama di Nusa Tenggara Timur, sementara hampir segenap penduduknya beragama. Dalam kehidupan masyarakat ada keyakinan yang kuat untuk mengenakan label tuduhan pada seseorang atau keluarga sebagai suanggi yang memiliki kekuatan mistis-magis yang dapat digunakan untuk mendatangkan penderitaan, penyakit dan kematian pada orang lain. Keyakinan ini diperoleh dari cerita-cerita seputar suanggi dan segala sepak terjang yang menakutkan dan dari dukun yang mengklaim diri dapat mengetahui rahasia penyebab penderitaan, penyakit, dan kematian pada manusia. Dengan demikian, orang atau keluarga yang satu mengenakan label atau stigma pada seseorang atau keluarga atau sekelompok orang sebagai yang hidup dari ongkos hidup orang lain.

Stigmatisasi suanggi seperti ini menimbulkan kesulitan dalam upaya pewartaan Sabda Allah. Terdapat gejala dualisme iman yang sedang hidup dalam masyarakat, khususnya yang beragama Katolik. Dualisme ini 
hanya dapat dieliminasi dengan usaha dan perjuangan para pewarta dan orang beriman untuk membebaskan diri dari superstisi dan fenomena berhala yang hidup di tengah masyarakat.

Teologi Katolik menegaskan bahwa kepercayaan dan praktik-praktik suanggi yang diceritakan tidak benar, irrasional dan berbahaya bagi Gereja sebagai kumpulan umat Allah yang sedang berziarah kepada keselamatan abadi dalam Yesus Kristus. Karena itu perjuangan melawan stigmatisasi suanggi dalam masyarakat merupakan usaha evangelisasi untuk membebaskan umat beriman dari kesinpangsiuran kepercayaan yang tidak benar. Ditawarkan kepada umat beriman untuk menghayati dan mengamalkan cinta kasih yang diwartakan dan dihidupi Yesus Kristus, sebagai pokok iman, menjadi pedoman, pijakan dan arah perjuangan melawan stigmatisasi suanggi. Yesus mengajarkan: "Kasihilah Tuhan Allahmu, dengan segenap hatimu dan dengan segenap jiwamu dan dengan segenap akal budimu...dan kasihilah sesamamu manusia seperti dirimu sendiri", (Mt 22: 37.39). Ini adalah perintah utama Kristus bagi semua pengikut-Nya.

\section{Daftar Rujukan:}

Arndt, William, F. and F. Wilbur Gingrich. 1979. A Greek-English Lexicon of the New Testament and Other Early Christian Literature, $2^{\text {nd }}$ ed. The University of Chicago Press, Chicago and London.

Ceme, Remigius. 2015.Hubungan antara Umat Katolik Paroki St. Joanne Baptista Wolosambi dan Umat Beragama Lain dan Kepercayaan Asli. Dalam Remigius Ceme dan Innocentius Soka Mali Lengga, (ed.). 2015. Gemerlap Intan Karya Tuhan. Moya Sam Sam, Yogyakarta.

Embuiru, Herman. Pen. 1995.Katekismus Gereja Katolik. Arnoldus, Ende.

Kirchberger, Georg. 2008. Allah Menggugat. Sebuah Dogmatik Kristiani. Ledalero, Maumere.

Pranjana, Stefanus. 2005.Setan Menurut Orang Katolik Prespektif Perjanjian Baru. Kanisius, Yogyakarta

Zocca, Franco and Jack Urame. 2008.Sorcery, Witchcraft and Christianity in Melanesia. 